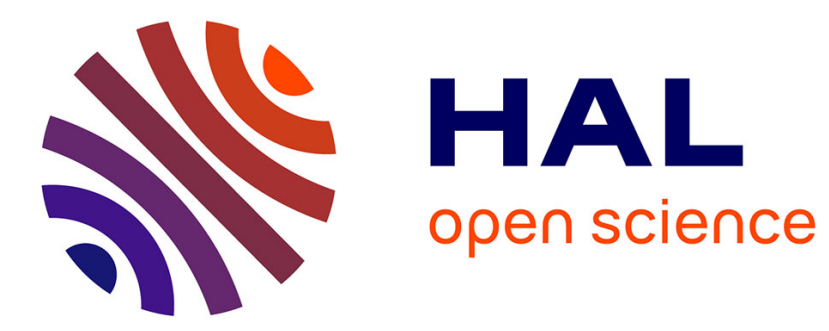

\title{
Climate-energy-water nexus in Brazilian oil refineries
}

Fernanda Guedes, Alexandre Szklo, Pedro Rochedo, Frédéric Lantz, Leticia Magalar, Eveline Maria Vásquez Arroyo

\section{To cite this version:}

Fernanda Guedes, Alexandre Szklo, Pedro Rochedo, Frédéric Lantz, Leticia Magalar, et al.. Climateenergy-water nexus in Brazilian oil refineries. International Journal of Greenhouse Gas Control, 2019, 90, pp.102815. 10.1016/j.ijggc.2019.102815 . hal-02305462

\section{HAL Id: hal-02305462 \\ https://hal-ifp.archives-ouvertes.fr/hal-02305462}

Submitted on 4 Oct 2019

HAL is a multi-disciplinary open access archive for the deposit and dissemination of scientific research documents, whether they are published or not. The documents may come from teaching and research institutions in France or abroad, or from public or private research centers.
L'archive ouverte pluridisciplinaire HAL, est destinée au dépôt et à la diffusion de documents scientifiques de niveau recherche, publiés ou non, émanant des établissements d'enseignement et de recherche français ou étrangers, des laboratoires publics ou privés. 


\section{Climate-energy-water nexus in Brazilian oil refineries}

2 Fernanda Guedes ${ }^{1}$, Alexandre Szklo ${ }^{1}$, Pedro Rochedo ${ }^{1}$, Frédéric Lantz ${ }^{2}$, Leticia Magalar ${ }^{1}$, Eveline Maria

3 Vásquez Arroyo ${ }^{1}$

4

${ }^{1}$ Energy Planning Program, Graduate School of Engineering, Universidade Federal do Rio de Janeiro, Centro de Tecnologia, Bloco C, Sala 211, Cidade Universitária, Ilha do Fundão, 21941-972 Rio de Janeiro, RJ, Brazil

${ }^{2}$ IFP School, 232 Avenue Napoléon Bonaparte, 92852 Rueil-Malmaison, France

\section{$8 \quad$ Abstract}

9 Oil refineries are major $\mathrm{CO}_{2}$ emitters and are usually located in water-stress sites. While some $10 \mathrm{CO}_{2}$ mitigation options can reduce water withdrawals, others can increase it, and still others are neutral. By simulating two parametric models, one for all Brazilian refineries, and the other locally detailing the water balance of the country's largest refinery, this study aimed to quantify the impacts of $\mathrm{CO}_{2}$ mitigation options on the water use of oil refineries. Findings show that, at 25 and $100 \mathrm{US} \$ / \mathrm{tCO}_{2}$, Brazilian refineries can abate $\mathrm{CO}_{2}$ emissions by $10 \%$ and $26 \%$, respectively, compared to current emissions. A relevant share of this abatement derives from the implementation of carbon capture facilities in fluid catalytic cracking and hydrogen generation units. However, these $\mathrm{CC}$ facilities offset the co-benefits of other $\mathrm{CO}_{2}$ mitigation options that can reduce steam and cold water requirements in refineries. In fact, for the largest Brazilian oil refinery, the implementation of all mitigation measures had almost no effect on its water balance. This means that $\mathrm{CO}_{2}$ abatement in refineries has no significant impact on water consumption (no negative trade-off). However, this also means that the water stress in oil refineries should be dealt with with measures not directly linked to $\mathrm{CO}_{2}$ abatement (no significant co-benefits).

Keywords: Climate-energy-water nexus; oil refineries; Brazil.

\section{Introduction}

Two of the UN Sustainable Development Goals (SDGs) focus on achieving physical and economic access to energy and water in quantity and quality. SDG7 aims to provide affordable, secure, sustainable and modern energy for all; furthermore, SDG6 aims to provide available and sustainable management of water and sanitation for all (UN, 2016). Energy and water are key elements closely linked to all other sectors within an economy. They also interact closely in many aspects (BIGGS et al., 2015). In this way, achieving the goal of a natural resource will influence the fulfillment of the other goal. For instance, water is needed at all stages of energy 
production, while water management, treatment and transportation require energy. Moreover, global climate change can add a significant amount of uncertainty to these complex interrelations. Changes in climate variables, such as precipitation and temperature, can affect water and energy resources, increasing their vulnerabilities. Also, the strategies to tackle climate change by reducing (mitigating) greenhouse-gas (GHG) emissions can affect the water-energy nexus (HOWELLS et al., 2013).

For instance, coal-fired thermoelectric plants need water resources, mainly for cooling processes. For these plants, a promising GHG mitigation option could be the installation of amine-based carbon capture (CC) systems (ROCHEDO and SZKLO, 2013). However, CC would also increase both water withdrawal and consumption by the thermoelectric plant by more than $100 \%$, which may intensify its vulnerability and affect the water supply to other users downstream from the power plant (ZHAI and RUBIN, 2011; MERSCHMANN et al., 2012). In the case of the production of liquid biofuels, the nexus goes beyond the energy conversion facility, which may also be affected by $\mathrm{CO}_{2}$ mitigation options, and mostly refers to the biomass production, which usually represents a significant share of water consumption (irrigation) in countries such as Brazil (IEA, 2016). Interestingly enough, the increase of biomass productivity arising from irrigation is an emblematic case of the tradeoff between GHG mitigation and water.

At the end, given all these complex and interconnected relationships, an integrated analysis is needed to evaluate the nexus between energy-water under the challenges associated with climate change (HOWELLS et al., 2013). In addition, each energy sector needs a proper analysis to quantify this nexus. For this study, this analysis is performed at both country and local level. On one hand, the country level provides the basic answer for the primary research question of this study, which is: do $\mathrm{CO}_{2}$ mitigation options affect the water consumption of an oil refinery system (or even: what could the nexus be between the carbon mitigation cost curve and the water consumption in refineries)? On the other hand, the detailed local level analysis, whose focus is on a specific oil refinery, allows the answering of the secondary question of this study, which is: do the impacts of climate mitigation options on water consumption affect the water supply-demand balance of an oil refinery? Only local level analyses can solve this secondary question, since it requires the proper evaluation of water sources (water supply) and sinks (water users).

In fact, oil refining is an energy-intensive activity, whose greenhouse gas (GHG) emissions are closely related to the combustion and chemical conversion of fossil fuels. The fuel combustion in oil refineries is related to the generation of direct heat, process steam and even electricity, all in stationary sources. The refineries' technological schemes are complex (GOMES et al., 2009; COELHO and SZKLO, 2015), depending on the characteristics of the feedstocks, the units' 
capacities, the production profile of the oil products (quantities and specifications), and the choice of technologies to be used (CASTELO BRANCO et al., 2011). For instance, refineries that process heavy crude oils to output light products present process schemes that use more final energy, and in turn emit more GHG (EPA, 2010). In addition, the more stringent the oil derivative specifications, the greater the energy and water consumption of the refining process, due to the need of severe hydro-treatment units, which use the hydrogen produced in units emitting $\mathrm{CO}_{2}$ from the steam reforming of light hydrocarbons (SZKLO and SCHAEFFER, 2007; CONCAWE, 2012; SUN et al., 2018). In 2012, oil refineries accounted for $2.7 \%$ of US, $3.2 \%$ of European Union and $2.0 \%$ of Brazil $\mathrm{CO}_{2}$ emissions (MCTI, 2013; PETROBRAS, 2013; EPA, 2014).

Nevertheless, the vast majority of the research associated with the nexus between energy and climate in oil refineries has focused on the trade-off between fuel specifications and $\mathrm{CO}_{2}$ emissions (CONCAWE, 2000; CHAN, 2006; SZKLO AND SCHAEFFER, 2007; JOHANSSON et al., 2012; CONCAWE, 2012). In the case of the nexus between energy and water, there are some studies on the relationship between water consumption and energy use in oil refineries (HIGHTOWER and PIERCE, 2008; IPIECA, 2010; HWANG and MOORE, 2011; PAN et al., 2012; MUGHEES and AL-AHMAD, 2014; SUN et al., 2018). Previous research has also focused on the implementation of $\mathrm{CO}_{2}$ capture in oil refineries and its abatement cost, as ROCHEDO et al. (2016) have done, but it has failed to explore the water nexus with $\mathrm{CO}_{2}$ mitigation options in oil refineries.

At the end, few attempts have been made to quantify the relationship between climate $\left(\mathrm{CO}_{2}\right.$ emission mitigation) and water-energy use in oil refineries. Table 1 provides a brief summary of the opportunities for $\mathrm{CO}_{2}$ abatement measures in oil refineries' processing units, and their likely impact on water consumption. It highlights the signs of the impacts that are quantified later in this study (positive and negative signs) through the use of simulation tools for all Brazilian refineries and for a specific refinery in detail.

Table 1 - Qualitative Impacts on Water Consumption of $\mathrm{CO}_{2}$ Mitigation Options in Oil Refineries

\begin{tabular}{|c|c|c|c|c|c|c|c|}
\hline Process Unit & 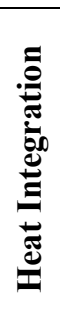 & 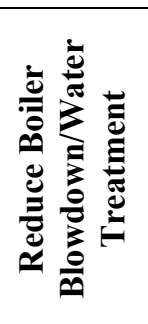 & 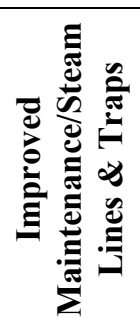 & 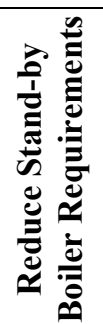 & 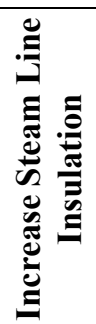 & 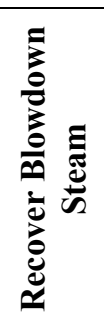 & U \\
\hline ADU & - & - & - & - & - & & \\
\hline VDU & - & - & - & - & - & & \\
\hline CRU & & - & & - & & - & \\
\hline HDT & - & - & - & - & - & - & \\
\hline
\end{tabular}




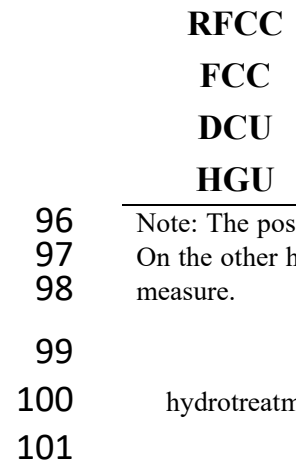

Source: WORREL and GALITSKY (2003); WORREL and GALITSKY (2005); CONCAWE (2008); BERGH, 2012; MORROW III et al. (2013)

Regarding water use, oil refining requires considerable amounts of water, which vary significantly between refineries, depending on the process configuration (WU and CHIU, 2011; SUN et al., 2018), the petroleum specification (e.g., density, sulphur content, total acid number) (SUN et al., 2018), and the products' requirements. Within this context, in Brazilian refineries, water requirements deserve attention due to the processing of heavy-to-medium crude oils, as well as to the increasingly stringent specifications of fuels that require the implementation of hydrotreatment units, associated with the water-intensive steam reforming process (CASTELO BRANCO et al., 2010; SZKLO, ULLER and BONFÁ, 2012; BARROS and SZKLO, 2015) ${ }^{1}$.

In addition, in Brazil, water availability is not evenly distributed. While the northern region holds more than $80 \%$ of all water availability, the basins located in large urban centers, in the Brazilian southeast, for example, are currently facing low water availability coupled with high withdrawals. As shown in Figure 1, most Brazilian refineries are already dealing with water stress, measured in relation to the level of water criticality of watersheds. This index measures the ratio between water withdrawals for consumptive uses (irrigation, water supply, urban and industrial) and the water availability of each sub-basin expressed through the value of average flow with permanence of 95\%. In fact, REPLAN, REVAP, RLAM and REDUC, which account

\footnotetext{
${ }^{1}$ In 2018, the Brazilian oil refining industry consisted of 17 refineries in operation, with a total installed nominal capacity of $2.2 \mathrm{Mbbl} / \mathrm{day}$ (ANP, 2018). Most Brazilian refineries were built before the 1980s with the objective of meeting the demand for gasoline and fuel oil in major urban centers (also close to Brazil's coast). However, due to the increasing diesel demand after the 1980s (BORBA et al., 2017), as well as the ramp up of medium-to-heavy crude oil production in Brazilian offshore basins in the 1980s and 1990s (HALLACK et al., 2017), the refining schemes of existing refineries were altered to convert the heaviest fractions of crude into medium cuts - e.g., by adding delayed coking units and severe hydrotreatment processes (which remove nitrogen compounds, high sulfur compounds and aromatic rings) (SZKLO and SCHAEFFER, 2007; SZKLO et al., 2012).
} 
121 for 54\% of Brazil's refining capacity, are located in areas classified as having critical water 122 availability.

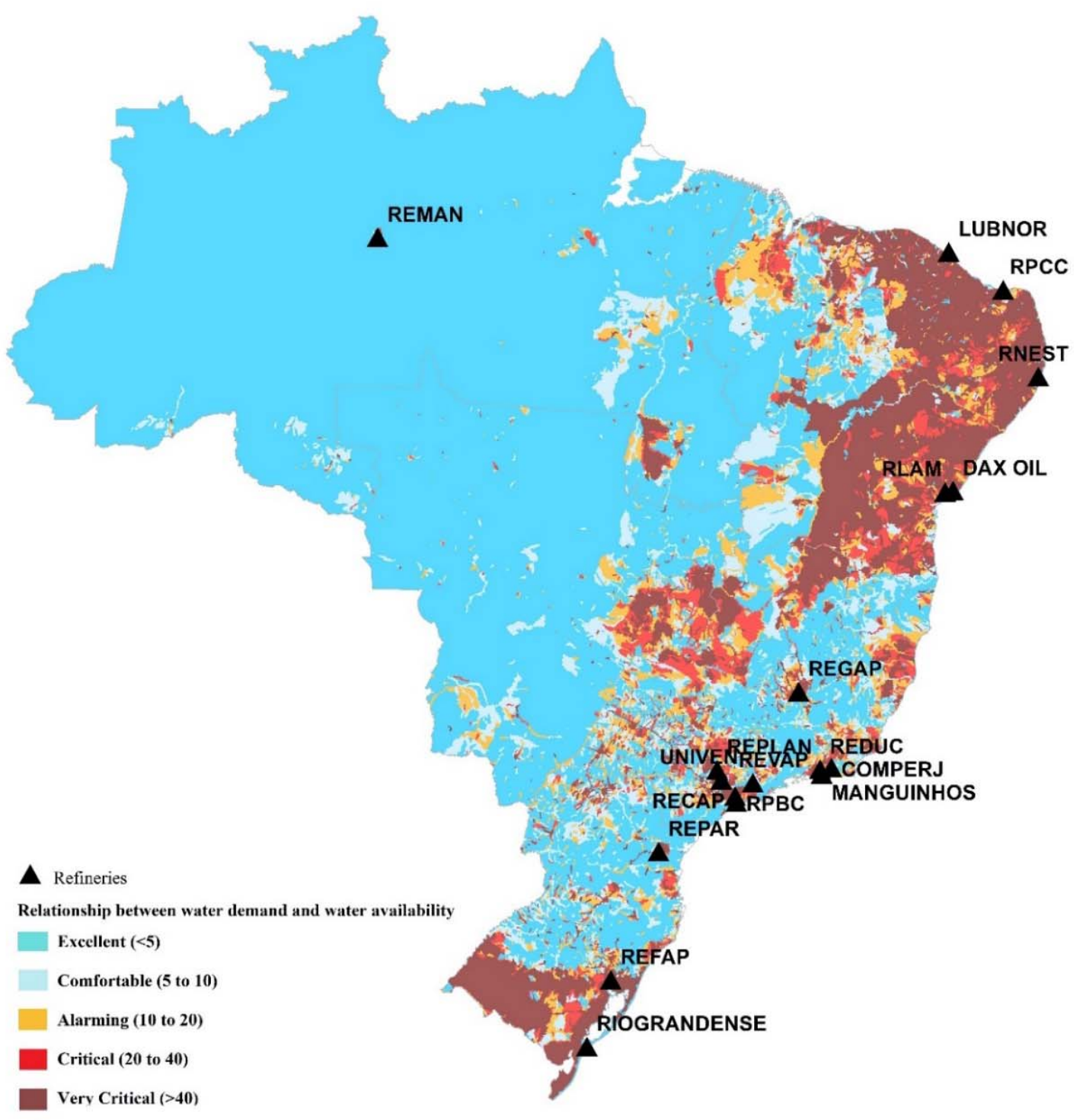

Figure 1 - Refineries locations and water criticality indicator of sub-basins in Brazil

Source: Based on ANA (2017)

128 To sum up, oil refineries are major $\mathrm{CO}_{2}$ emitters and are usually located in sites with already critical availability supply of water. This is the case for Brazil, but it can be seen worldwide

130 (OIL and GAS JOURNAL, 2018). Some $\mathrm{CO}_{2}$ emission mitigation measures can positively or negatively influence both withdrawal and water consumption at refineries. Within this context,

132 this study aims to quantify the extent to which these measures can impact refineries' water use.

133 First, by developing an energy, $\mathrm{CO}_{2}, \mathrm{H}_{2}$, water balance simulator for Brazilian oil refineries, and 
applying it to different scenarios of $\mathrm{CO}_{2}$ mitigation, this study evaluates the $\mathrm{CO}_{2}$ mitigationenergy-water nexus at the country level. Then, this study analyzes the water supply of the hydrographic basin in which the largest Brazilian refinery, REPLAN, is located and how it behaves over time. This detailed analysis, at a local level, not only quantifies the water withdrawal impacts of $\mathrm{CO}_{2}$ mitigation options, but also identifies whether or not these impacts could be overcome by the current water supply of this specific refinery.

The next section presents the methodology used to carry out the analysis, as well as a brief description of the simulation tools applied. Section 3 discusses the results obtained. Lastly, the final remarks of the study, highlighting also its limitations, are presented.

\section{Methods}

\subsection{Methodological Procedure}

The methodological procedure applied by this study consisted of the following steps. The first step is the definition of GHG mitigation measures in oil refineries, according to the scientific literature and the experience of the authors regarding Brazil's oil refineries ${ }^{2}$. Then, the study simulates the baseline case for estimating the scenario without $\mathrm{CO}_{2}$ mitigation, and simulates the impacts of introducing $\mathrm{CO}_{2}$ price scenarios into oil refineries, in terms of $\mathrm{CO}_{2}$ emissions, final energy use and water consumption. This provides the carbon mitigation cost curve, and also helps to identify (quantify) the impacts of GHG mitigation options on the water consumption for all Brazilian refineries. However, this step is not able to detail the water supply balance at a local level. Therefore, using the mitigation cost curve for Brazilian refineries (mentioned above), the proposed procedure includes a last step for detailing the case of the largest Brazilian oil refinery, REPLAN. This step not only quantifies the water consumption impacts of $\mathrm{CO}_{2}$ mitigation options, but also identifies whether these impacts could be overcome by the current water supply of REPLAN. In summary, the steps include:

1. To assess the $\mathrm{CO}_{2}$ mitigation options focusing on the saving potential for the consumption of fuels, steam, electricity and $\mathrm{H}_{2}$.

2. To estimate the energy and mass balances for a baseline case, including final energy consumption, $\mathrm{CO}_{2}$ emissions and water requirements. This case does not consider the application of $\mathrm{CO}_{2}$ emission mitigation options (e.g., fuel switch, fuel saving and carbon capture). This study applies an energy and mass balance simulator - the so-called

\footnotetext{
${ }^{2}$ See, for instance, GUEDES (2015).
} 
"CAESAR - Carbon and Energy Strategy for Refineries" tool, which is briefly described here, and better described in the Supplementary Material.

3. To run CAESAR with $\mathrm{CO}_{2}$ emission prices ${ }^{3}$ of $25,50,100$ and $200 \mathrm{US} \$ / \mathrm{tCO}_{2}$. In this case, the $\mathrm{CO}_{2}$ emissions mitigation options are selected according to their marginal abatement cost - that is, technological options with costs lower than or equal to the exogenously established $\mathrm{CO}_{2}$ price are automatically selected by the simulation tool, allowing the construction of a $\mathrm{CO}_{2}$ average abatement cost curve for all Brazilian oil refineries. The Supplementary Material provides the basic equation associated with the estimation of the abatement cost.

4. To develop a case study for REPLAN, the largest Brazilian refinery in terms of processing capacity, thus quantifying the water stress in detail, or locally. This allows investigating whether mitigation measures that were selected in step 3 can be adopted in cases where a greater water withdrawal is required. This case study is performed using the software tool Water Evaluation and Planning - WEAP (see section 2.2. and Supplementary Material).

\subsection{CAESAR tool - Carbon and Energy Strategy Analysis for Refineries}

The tool used for evaluating all Brazilian refineries, without detailing the water supply-demand balance at a local level, is the simulator CAESAR - Carbon and Energy Strategy Analysis for Refineries. It was originally developed by TOLMASQUIM and SZKLO (2000), later being used by the Brazilian Government in its Long-Term Energy Plan 2030 (EPE, 2007). Finally, it was updated by GUEDES (2015) and by VÁSQUEZ-ARROYO (2018) and MAGALAR (2018) for incorporating water balances.

The simulation is performed within Excel (visual basic), and relies on refining schemes, including the following units' energy and mass balances: atmospheric distillation, vacuum distillation, alkylation, atmospheric residue delayed coking, vacuum residue delayed coking, propane desasphalter, catalytic reformer, fluid catalytic cracker, hydrocracker, residue fluid catalytic cracker, hydrotreaters (naphtha, diesel, kerosene and instable products), hydrotreatment of finished gasoline, lube unit, and hydrogen generation unit. The processing units' capacities are determined, as well as the processed feedstocks, specific utilities consumption (steam, fuel and hydrogen) and specific water consumption. The outputs of the tool consist of the final energy consumption, $\mathrm{CO}_{2}$ emissions, oil product output, and refineries' water consumption and withdrawal.

\footnotetext{
${ }^{3}$ They represent an established price to be paid for a given amount of $\mathrm{CO}_{2}$ emitted.
} 
201 Therefore, CAESAR is a bottom-up model mostly based on the simulation of the mass (water,

$202 \mathrm{H}_{2}$ ) and energy balances of Brazilian oil refineries. It has an additional feature for optimizing

203 the energy consumption aimed at minimizing the cost of operation of oil refineries. The model

204 also includes a list of $\mathrm{CO}_{2}$ mitigation options, which are detailed according to the processing

205 units in which they can be implemented, their potential for saving fuel and/or electricity, their

206 investment, operation and maintenance costs, and their penetration rates. In total, 204 options of

207 technologies are available in CAESAR (see Supplementary Material for detailed data).

208 For the carbon price scenarios, $\mathrm{CO}_{2}$ emission prices were exogenously introduced into the 209 simulator, which also affected the optimization problem that finds the least-cost fuel mix of 210 refineries. Prices of $25,50,100$ and $200 \mathrm{US} \$ / \mathrm{tCO}_{2}$ were considered, thus building five different 211 scenarios for the current configuration of Brazilian oil refineries. As $204 \mathrm{CO}_{2}$ emission

212 mitigation options are available in the simulator, their abatement costs range from negative 213 values, which represent "non-regret" measures, to values above $100 \mathrm{US} \$ / \mathrm{tCO}_{2}$. The highest cost 214 measures would hardly come into effect without economic incentives or more robust 215 technological learning.

216 Therefore, depending on the $\mathrm{CO}_{2}$ emission price applied, the tool automatically selects different 217 GHG mitigation options from the set list available, affecting the final energy use, $\mathrm{CO}_{2}$ emissions 218 and water consumption. The Supplementary Material includes the basic data of the model and a 219 description of how to run it.

\subsection{WEAP}

222

Before using the tool WEAP, REPLAN mass and energy balances were simulated in the abovedescribed tool, CAESAR. This aimed to quantify the impacts of $\mathrm{CO}_{2}$ emission mitigation options on the water required by REPLAN. Then, the results of water withdrawals obtained in CAESAR were inserted as input into the WEAP tool. This is a tool for integrated water resources management (IWRM) developed by the Stockholm Environmental Institute (SEI). WEAP integrates physical hydrological processes with water withdrawal management and infrastructure, as well as environmental and economic aspects of water planning. Its simulations are based on scenarios that can be analyzed according to different trends in hydrology, water use and demand, demography, technology, operating rules and water management policies (SIEBER and PURKEY, 2015).

The WEAP analysis consists of, firstly, configuring the time horizon, catchment areas, system components and configuration of the problem to be evaluated. Then, the model is used to 
235 simulate alternative scenarios to assess the impact of different water supply and demand management options, as well as evaluate the water availability within a region of study.

237 The model simulates the use of water in hydrological basins by using a linear programming algorithm, which aims to maximize the water delivered to demand sites, according to a set of priorities defined by the user. When water is limited, the algorithm is formulated to progressively constrain water allocation to the lowest priority demand sites. More details of the model can be found in SIEBER and PURKEY, 2015. See the Supplementary Material for further details on how WEAP is calibrated and used by this study.

The analysis performed by this study was based on the current Brazilian oil refinery system, thus, no greenfield refinery was constructed in the simulation. The mass and energy balances rely on the breakdown in processing units, which have specific characteristics. The capacity of these units is shown in Table 2. The average utilization factor of the atmospheric distillation unit was set as 70\%, following MME (2018).

Table 2 - Brazilian Process Unit Capacities as of December 2017

\begin{tabular}{cc}
\hline Unit & Capacity (barrels/d) \\
\hline ADU & $2,138,000$ \\
VDU & 804,740 \\
FCC & 378,729 \\
RFCC & 123,158 \\
ALK & 6,290 \\
DCU & 115,319 \\
CRU & 2,386 \\
HDS G & 3,054 \\
HDT N & 10,528 \\
HDT Q & 28,125 \\
HDT D & 200,041 \\
HDT I & 11,698 \\
LUB & 20,009
\end{tabular}


262 Table 3 shows the estimates for Brazilian refineries' typical utility consumption (negative 263 values mean a net production of the utility by the unit). Although there are variations in the 264 specific energy consumption of utilities for the same unit, depending on the supplier of the 265 technology, local characteristics or even different design considerations, the values adopted in 266 CAESAR seek to represent a typical Brazilian unit.

267

Table 3 - Process Units' Utilities Specific Energy Consumption

\begin{tabular}{|c|c|c|c|c|c|c|c|c|c|c|}
\hline \multirow[t]{2}{*}{ Unit } & $\begin{array}{c}\text { HP } \\
\text { Steam }\end{array}$ & $\begin{array}{c}\text { MP } \\
\text { Steam }\end{array}$ & $\begin{array}{c}\text { LP } \\
\text { Steam } \\
\end{array}$ & Electricity & Fuel & Coke & $\begin{array}{c}\mathbf{H}_{2} \\
\text { Consumption }\end{array}$ & $\begin{array}{c}\mathrm{H}_{2} \\
\text { Production }\end{array}$ & BFW & $\mathbf{C W}$ \\
\hline & $\mathrm{kg} / \mathrm{bbl}$ & $\mathbf{k g} / \mathbf{b b l}$ & kg/bbl & kWh/bbl & $\mathbf{M J} / \mathbf{b b l}$ & $\mathbf{M J} / \mathbf{b b l}$ & $\mathbf{m}^{3} / \mathbf{b b l}$ & $\mathbf{m}^{3} / \mathbf{b b l}$ & $\mathbf{m}^{3} / \mathbf{b b l}$ & $\mathbf{m}^{3} / \mathbf{b b l}$ \\
\hline ADU & 0.00 & 11.00 & 0.00 & 0.60 & 127.00 & 0.00 & 0.00 & 0.00 & 0.02 & 0.35 \\
\hline VDU & 0.00 & 0.00 & 0.00 & 0.00 & 0.00 & 0.00 & 0.00 & 0.00 & 0.05 & 0.35 \\
\hline FCC & -16.00 & 20.00 & -3.60 & 8.80 & 0.00 & 368.00 & 0.00 & 0.00 & 0.07 & 1.00 \\
\hline $\begin{array}{c}\text { RFC } \\
\mathbf{C}\end{array}$ & -18.00 & 0.00 & 0.00 & 1.00 & 0.00 & 368.00 & 0.00 & 0.00 & 0.07 & 1.00 \\
\hline ALQ & 0.00 & 90.00 & 0.00 & 9.00 & 0.00 & 0.00 & 0.00 & 0.00 & 0.05 & 7.00 \\
\hline CRU & -15.60 & 0.00 & 0.00 & 10.00 & 382.00 & 0.00 & -48.00 & 0.00 & 0.02 & 1.74 \\
\hline DCU & 0.00 & -18.40 & 0.00 & 3.60 & 126.00 & 0.00 & 0.00 & 0.00 & 0.06 & 2.03 \\
\hline $\begin{array}{c}\text { HDS } \\
\text { G }\end{array}$ & 3.00 & 0.00 & 0.00 & 2.00 & 105.00 & 0.00 & 4.00 & 0.00 & 0.04 & 0.96 \\
\hline $\begin{array}{l}\text { HDT } \\
\mathbf{N}\end{array}$ & 3.00 & 0.00 & 0.00 & 2.00 & 105.00 & 0.00 & 7.00 & 0.00 & 0.01 & 0.19 \\
\hline $\begin{array}{c}\text { HDT } \\
\mathbf{Q}\end{array}$ & 4.00 & 0.00 & 0.00 & 3.00 & 158.00 & 0.00 & 7.00 & 0.00 & 0.18 & 0.49 \\
\hline $\begin{array}{l}\text { HDT } \\
\text { D }\end{array}$ & 4.00 & 0.00 & 0.00 & 3.00 & 158.00 & 0.00 & 7.00 & 0.00 & 0.04 & 0.73 \\
\hline $\begin{array}{c}\text { HDT } \\
\text { I }\end{array}$ & 5.00 & 0.00 & 0.00 & 6.00 & 211.00 & 0.00 & 17.00 & 0.00 & 0.05 & 0.71 \\
\hline LUB & 0.00 & 1.60 & 5.60 & 1.60 & 135.00 & 0.00 & 0.00 & 0.00 & 0.05 & 1.00 \\
\hline HGU & 0.00 & 0.00 & 0.00 & 0.00 & 2.55 & 0.00 & 0.00 & 0.16 & 0.00 & 0.00 \\
\hline
\end{tabular}

274 For Brazilian oil refineries, as of 2017, coefficients of water withdrawals per process unit were 275 determined, as indicated in Table 4. The coefficients consist of low-pressure steam (LP Steam), 276 medium-pressure steam (MP Steam) and high-pressure steam (HP Steam), related to the process 277 units. The water balance also includes the water consumed in the cooling system (CW - cooling 278 water) and the volume of demineralized water used in the boiler (BFW - boiler feed water) per 279 barrel of oil processed. Figure 2 shows the basic water balance applied in the simulation tool. 
Table 4 - Water Use Coefficients per Process Unit

\begin{tabular}{cccccc}
\hline & $\begin{array}{c}\mathbf{C W} \\
\left(\mathbf{m}^{\mathbf{3}} / \mathbf{b b l}\right)\end{array}$ & $\begin{array}{c}\mathbf{B F W} \\
\left(\mathbf{m}^{\mathbf{3}} / \mathbf{b b l}\right)\end{array}$ & $\begin{array}{c}\text { LP Steam } \\
(\mathbf{k g} / \mathbf{b b l})\end{array}$ & $\begin{array}{c}\text { MP Steam } \\
(\mathbf{k g} / \mathbf{b b l})\end{array}$ & $\begin{array}{c}\text { HP Steam } \\
(\mathbf{k g} / \mathbf{b b l})\end{array}$ \\
\hline ADU & 0.3 & 0.02 & - & 11.0 & - \\
VDU & 0.3 & 0.05 & - & - & - \\
FCC & 1.0 & 0.07 & 3.6 & 20.0 & 16.0 \\
RFCC & 1.0 & 0.07 & - & - & 18.0 \\
ALQ & 7.0 & 0.05 & - & 90.0 & - \\
CRU & 1.7 & 0.02 & - & - & 15.6 \\
DCU & 2.0 & 0.06 & - & 18.4 & - \\
HDS G & 1.0 & 0.04 & - & - & 3.0 \\
HDT N & 0.2 & 0.01 & - & - & 3.0 \\
HDT Q & 0.5 & 0.18 & - & - & 4.0 \\
HDT D & 0.7 & 0.04 & - & - & 4.0 \\
HDT I & 0.7 & 0.05 & - & - & 5.0 \\
LUB & 1.0 & 0.05 & - & - & - \\
HGU & - & - & - & - & - \\
\hline HP - high pressure; MP - medium pressure; LP - low pressure; BFW - boiler feed water; CW - cooling \\
\end{tabular}

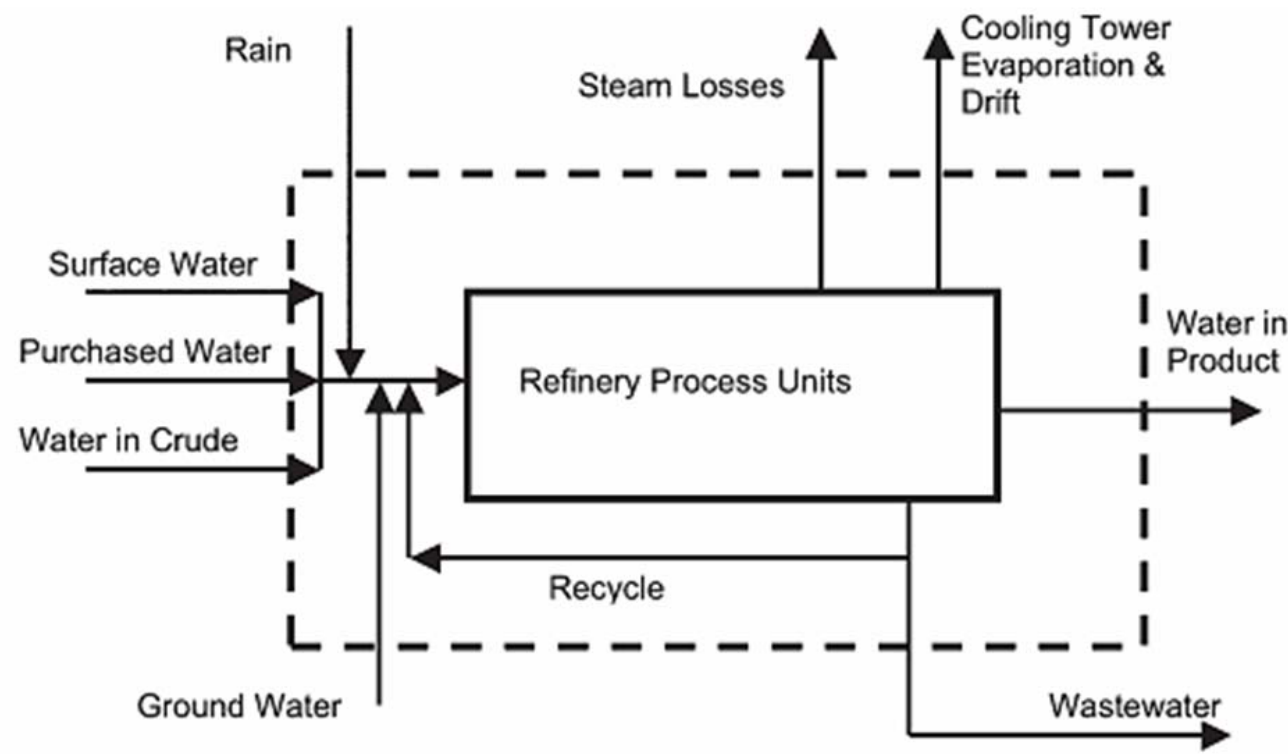


After obtaining the steam demand, $\mathrm{CW}$ and $\mathrm{BFW}$, parameters were adopted to estimate the water consumed by the refinery, based on ANZE (2013). They are composed of the make-up water used in the cooling towers, the make-up water for the boilers and the water used by the processes (water incorporated into products, for instance, in the production of $\mathrm{H}_{2}$, because of steam reforming and water gas shift, during chemical reactions). A value of $1.7 \%$ was considered for the cooling system's total circulating water, according to typical Brazilian oil refineries' concentration ratios (MAGALAR, 2018). For the boiler water make-up, a value of $49.7 \%$ was applied to the sum of the amount of water used in the boilers (BFW) and the total amount of steam consumed in process units. Steam consumed is defined as lost steam that did not return as condensate. For this, a value of $33 \%$ of all generated steam was used (VÁSQUEZ ARROYO et al., 2016). Equation (1) summarizes these assumptions and the water balance.

$$
\text { Demand }=\left(0.017 \times \sum_{i} C W_{i}\right)+\left\{0.497 \times \sum_{i} B F W_{i}+\left[0.33 \times \sum_{i} \text { Steam }_{i}\right]\right\}
$$

Where "CW" represents the cooling system's circulating water of each process unit " $\mathrm{i}$ "; "BFW" is the amount of water used in boilers of each process unit "i"; "Steam ${ }_{i}$ " is steam consumed in each process unit " $i$ ".

\subsubsection{REPLAN Case Study in WEAP}

REPLAN is the largest Brazilian refinery in terms of processing capacity (66 thousand $\mathrm{m}^{3} / \mathrm{day}$ ) (ANP, 2018). This refinery is located in Paulínia in the state of São Paulo and is placed in the Piracicaba, Capivari and Jundiaí River Basin (PCJ), which is classified as "critical" in relation to water availability (MAGALAR, 2018).

In this study, the water availability of Jaguari basin was calculated by simulating a water balance between the inflows and outflows of its drainage area over time. The Jaguari River basin was chosen due to the catchment point of REPLAN being located in this river. In addition, the basin of the Camanduacaia, Ribeirão do Pinhal rivers was integrated into the case study because these rivers are tributaries of the Jaguari River.

The water balance method chosen by this study was the simplified coefficient Method - Rainfall Runoff, in which water requirements are calculated based on evapotranspiration and precipitation data. Twenty-six rainfall stations were evaluated within the three catchment areas: Jaguari River catchment and its tributary rivers, Camanducaia and Pinhal. The data loaded after 
treatment of the missing data and outliers was the monthly average rainfall. In order to use the mean value of evapotranspiration for each catchment area, the monthly average of all municipalities in each area was calculated. For more details of data, see Supplementary Material.

The water outputs considered in this study are the projected demands for public supply, industry, irrigation and for animal husbandry. These demands were identified and projected to the year 2040 to assess the extent to which water availability changes as a function of the multiple uses of water within the PCJ basin and whether the REPLAN could be impacted.

The demand for water for urban supply was calculated using a coefficient of water demand per inhabitant per day that was adjusted to account for the water losses in distribution. The same coefficient was used for the projection of water demand for future public supply. The method used for the estimation of the population of each city is described in the Supplementary Material.

Water consumption for animal husbandry was calculated from data on the number of animals per city and then calculated the product of the effective number of herds by a per capita coefficient of daily water consumption known as equivalent cattle for water demand. In order to estimate the industrial demand, the volume of water granted by industry in the water agency was consulted.

The demand for irrigation is calculated by multiplying the area under cultivation by the difference between the water requirement of the crop and the precipitation occurring over the cultivated area. For this, it is necessary to know the water demand of each crop, which is calculated from the reference evapotranspiration and crop coefficient.

After all climatic parameters, data on land use and water demands are inserted into the model, the observed values of the fluviometric stations are compared with the flow data modeled by WEAP. From the observed and simulated flow data, two calibration indices are calculated, the Nash-Sutcliffe efficiency index and the BIAS index.

To evaluate the water availability of the REPLAN catchment area, a minimum ecological flow was defined. The minimum flows most commonly used in Brazil are $\mathrm{Q}_{7,10}{ }^{4}$ or $\mathrm{Q}_{95}{ }^{5}$, depending on the state where the drainage area is located. According to the water resources committee of the PCJ (CBH-PCJ, 2000), areas considered critical are those in which the total water demand exceeds $50 \%$ of the minimum availability $\mathrm{Q}_{7,10}$. In addition, the water resources policy in the state of Sao Paulo determines that the volume of water withdrawal in the industrial sector

\footnotetext{
${ }^{4}$ Lowest flow on seven consecutive days for 10 -year return period.

${ }^{5}$ Flow with $95 \%$ of permanence over a period.
} 
should be reduced if the flow of the Jaguari River reaches the minimum flow established in specific gauge stations. Therefore, in the water balance simulation done by this study, the analysis tried to find out if periods of restriction of water for REPLAN could happen.

\section{Results}

\subsection{Baseline Scenario for all Brazilian Refineries}

The total consumption of utilities and fuels in existing Brazilian refineries is shown in Table 5. Negative values indicate exports or utility surpluses, while positive values indicate consumption of utilities.

Table 5 - Utilities Consumption

\begin{tabular}{cc}
\hline HP Steam (kt/year) & $-752,5$ \\
MP Steam (kt/year) & $7,340.4$ \\
LP Steam (kt/year) & -375.9 \\
Electricity (GWh/year) & $12,162.7$ \\
Fuel (TJ/year) & $284,018.2$ \\
Coke (TJ/year) & $58,952.6$ \\
$\mathbf{H}_{\mathbf{2}}$ (M Nm /year) & $6,116.5$ \\
\hline
\end{tabular}

$\mathrm{HP}$ - high pressure; MP - medium pressure; LP - low pressure

From the utilities consumption, it was possible to determine the fuel consumption. The refinery fuels include natural gas, refinery gas, fuel oil, naphtha and petcoke. Electricity purchased from the grid was also accounted for, either from those refineries that do not have cogeneration or from the excess demand in relation to the capacity of cogeneration units. Natural gas is used for producing hydrogen in HGUs, electricity in cogeneration units, and steam in boilers and direct heating in process units. Refinery gas and fuel oil were accounted for direct heating in process units. In general, leftover refinery gas was directed toward flare emissions accounting. Furthermore, a $100 \%$ flare combustion efficiency was assumed to be conservative on the GHG emission estimates. Finally, the consumption of petcoke was accounted for in FCC and RFCC units. Table 6 shows the estimation of the final energy consumption for the existing Brazilian refineries.

Table 6 - Final Energy Consumption - Baseline (PJ/year)

Natural Gas $\quad 367.8$


382

383

388

389

390

391

392

393

394

395

396

397

\begin{tabular}{cc} 
Refinery Gas & 84.4 \\
Fuel oil & 85.4 \\
Coke & 59.0 \\
\hline TOTAL & 596.6 \\
\hline Grid Eletricity $(\mathrm{GWh} /$ year $)$ & $7,252.7$ \\
\hline
\end{tabular}

As such, the water requirement of the existing Brazilian refineries is detailed in Table 7. The water intensity of $108.2 \mathrm{~m}^{3} / \mathrm{bbl}$ is compatible with the figures found in VANELLI (2004) for REVAP - Refinaria Henrique Lage; PETROBRAS (2005) and NOGUEIRA (2007) for REPLAN - Refinaria de Paulínia; SCHOR (2006) for REDUC - Refinaria Duque de Caixas; and CETESB (2011) for RPBC - Refinaria Presidente Bernardes.

Table 7 - Water Requirements - Baseline

\begin{tabular}{cc}
\hline BFW $(\mathrm{t} / \mathrm{h})$ & $8,809.2$ \\
CW $(\mathrm{t} / \mathrm{h})$ & $118,486.2$ \\
Steam $(\mathrm{t} / \mathrm{h})$ & $3,720.4$ \\
\hline Condensed Steam $(\mathrm{t} / \mathrm{h})$ & $2,492.7$ \\
\hline BFW spent $(\mathrm{t} / \mathrm{h})$ & $10,036.9$ \\
BFW Make-up $(\%)$ & 49.7 \\
BFW Make-up $(\mathrm{t} / \mathrm{h})$ & $4,988.4$ \\
\hline CW Make-up $(\%)$ & 1.7 \\
CW Make-up $(\mathrm{t} / \mathrm{h})$ & $2,014.3$ \\
\hline Consumption $(\mathrm{t} / \mathrm{h})$ & $1,610.5$ \\
Withdrawal $(\mathrm{t} / \mathrm{h})$ & $7,002.6$ \\
\hline Consumption $\left(\mathrm{m}^{3} / \mathrm{bbl}\right)$ & 24.9 \\
Withdrawal $\left(\mathrm{m}^{3} / \mathrm{bbl}\right)$ & 108.2 \\
\hline Consumption $\left(\mathrm{km}^{3} / \mathrm{year}\right)$ & 14107.9 \\
Withdrawal $\left(\mathrm{km}^{3} /\right.$ year $)$ & 61351.7 \\
\hline BFW - Boiler feed water; CW - Cooling water
\end{tabular}

It was also possible to estimate the $\mathrm{CO}_{2}$ emissions of Brazilian refineries as of 2017, through the multiplication of the emission factors reported by IPCC (2006) of the respective fuels used by Brazilian refineries (Table 8). For electricity's $\mathrm{CO}_{2}$ emissions, the average Brazilian grid emission factor for 2017 was considered, equal to $92.7 \mathrm{tCO}_{2} / \mathrm{GWh}$ (MCTIC, 2018).

Table 8 - $\mathrm{CO}_{2}$ Emissions ( $\mathrm{MtCO}_{2} /$ year) - Baseline

\begin{tabular}{cc}
\hline Natural Gas & 20.6 \\
Refinery Gas & 4.9 \\
Fuel Oil & 6.6 \\
Coke & 5.7
\end{tabular}

Grid Electricity $\quad 0.4$ 
399 By dividing the total emissions by the processed feed, this study estimated an emission intensity 400 of $0.4 \mathrm{tCO}_{2} / \mathrm{t}$ oil, which is compatible with the 2012 data presented by the Brazilian oil company 401 that owns most of the country's refineries (PETROBRAS, 2013) ${ }^{6}$. Just for comparison, 402 worldwide several works in the literature present $\mathrm{CO}_{2}$ emission intensities of oil refineries 403 hovering between 0.1 and $0.4 \mathrm{tCO}_{2} / \mathrm{t}$ of oil processed, with an average of 0.22 (CONCAWE, 404 2008; IEAGHG, 2008; STRAELEN et al., 2010; DNV, 2010). For example, the US has an 405 average emission of $0.33 \mathrm{tCO} 2 / \mathrm{t}$ of processed oil, while the European Union has an average 406 value of 0.27 (EPA, 2014).

407 Finally, concerning the relationship between $\mathrm{CO}_{2}$ emissions and water withdrawals, the

408

409

410 estimative for the baseline scenario is $0.62 \mathrm{tCO}_{2} / \mathrm{m}^{3}$. Figure 3 and Figure 4 present, for this scenario, the most representative units in terms of water consumption and $\mathrm{CO}_{2}$ emissions, respectively.

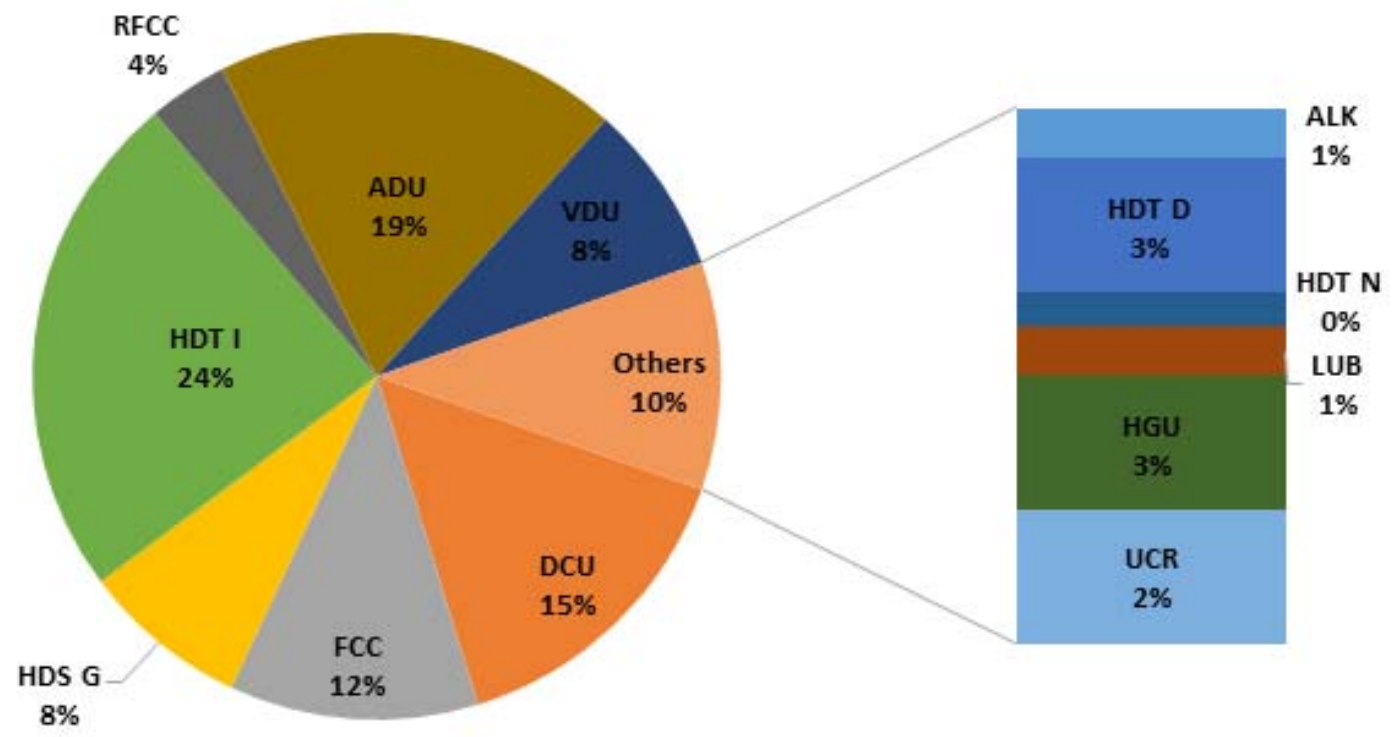

\footnotetext{
${ }^{6}$ Equal to $0.45 \mathrm{tCO}_{2} / \mathrm{t}$ of oil processed in 2012. Of course, this intensity may vary slightly among years given the focus of the ADU campaign (in our study we focused on diesel), the possible maintenance of downstream units, which can affect the utilization factor of oil refineries (we used the ADU average utilization factor of 2017 , equal to $70 \%$ ), and the crudes processed in the refineries. In our study, we have considered the ramp-up of a lighter and sweeter feed that has been made available in Brazil in the last five years, from pre-salt fields. That is why we run the model with $4 \%$ of the feed from paraffinic oils from Saudi Arabia; $2 \%$ from ultra-light African crudes; 32\% from Brazilian heavy crudes, and the remaining $62 \%$ from medium-to-slightly light Brazilian crudes, mostly from pre-salt fields. Therefore, the feedstock blend has become lighter than it was in 2012 .
} 
ADU - atmospheric distillation unit; VDU - vacuum distillation unit; ; FCC - fluid catalytic cracking; RFCC - resid fluid catalytic cracking; ALK - alkylation unit; DCU - delayed coking unit; CRU - catalytic reforming unit; HDS G - gasoline
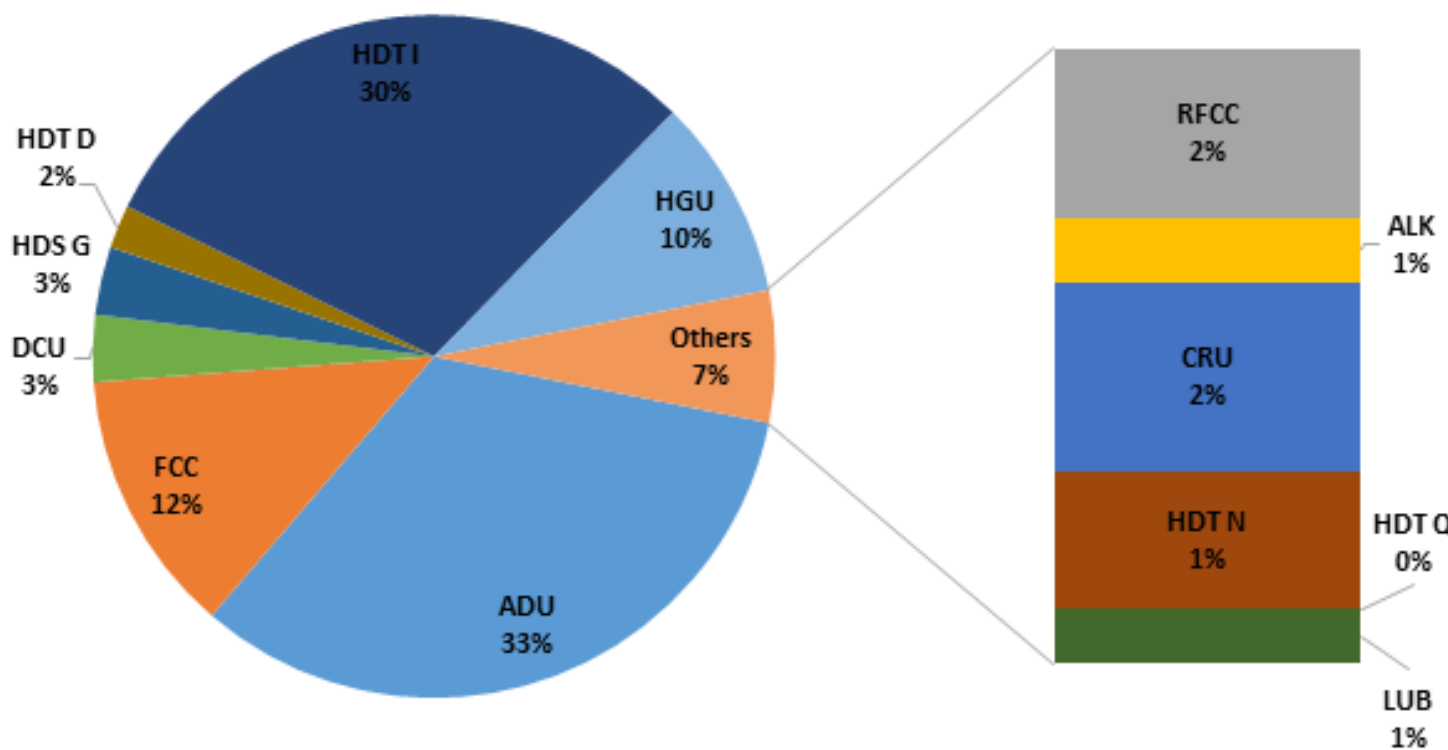

Figure 4 - $\mathrm{CO}_{2}$ emissions per processing unit in the baseline scenario

According to SZKLO and SCHAEFFER (2007), most $\mathrm{CO}_{2}$ emissions from Brazilian refineries come from burning fuels. Interestingly, the fuel consumption of refineries in absolute terms concentrates on few processes, which are not the most energy intensive (in terms of energy consumption per barrel) but process large volumes of feedstock. Typically, atmospheric and vacuum distillation units account for $35-40 \%$ of a refinery's final energy use (API, 2000) because any barrel of oil entering a refinery passes through the topping separation units. This explains their share of $\mathrm{CO}_{2}$ emissions. Also, for global refining, between $16 \%$ and $20 \%$ of the total are non-energy emissions associated with the chemical reactions of hydrogen production and cracking of the FCC (SZKLO AND SCHAEFFER, 2007). This average figure agrees with our findings for Brazil. Finally, severe hydrotreatment (for unstable and unfinished distillates) results in both higher water consumption and $\mathrm{CO}_{2}$ emissions due to the severity (temperature 
437 higher than $450^{\circ} \mathrm{C}, \mathrm{H}_{2}$ partial pressure up to $21 \mathrm{MPa}$, and low liquid hourly space velocity ${ }^{7}$ and 438 hydrogen pressure) under which reactions must happen (GARY et al, 2007; STANISLAU et al, 439 2010).

\section{2. $\mathrm{CO}_{2}$ Price Scenarios for all Brazilian Refineries}

As described above, four $\mathrm{CO}_{2}$ price scenarios were simulated in CAESAR. According to the levelized cost of mitigation options on the database of the tool, different options were selected for each scenario. Moreover, the fuel mix also changed to minimize operational costs considering the $\mathrm{CO}_{2}$ prices (and the emission factors of each possible fuel to be used). Table 9 summarizes the results for different $\mathrm{CO}_{2}$ prices, and Figure 5 shows $\mathrm{CO}_{2}$ emissions and water requirements for different $\mathrm{CO}_{2}$ emission prices scenarios.

Table 9 - Summary of Results

\begin{tabular}{|c|c|c|c|c|c|}
\hline \multirow{2}{*}{ Final Energy Use (PJ/year) } & \multicolumn{5}{|c|}{$\mathrm{CO}_{2}$ Emission Price (US\$/tCO} \\
\hline & Baseline & 25 & 50 & 100 & 200 \\
\hline Natural Gas & 367.84 & 367.84 & 367.84 & 367.84 & 367.84 \\
\hline Refinery Gas & 84.39 & 84.39 & 84.39 & 84.39 & 84.39 \\
\hline Fuel oil & 85.26 & 78.76 & 78.22 & 71.32 & 62.05 \\
\hline Coke & 58.95 & 58.95 & 58.95 & 58.95 & 58.95 \\
\hline TOTAL & 596.40 & 589.94 & 589.40 & 582.50 & 573.23 \\
\hline Grid Eletricity (GWh/year) & 7252.71 & 7393.02 & 7199.61 & 7772.97 & 7643.62 \\
\hline \multicolumn{6}{|c|}{ Water requirements } \\
\hline Consumption $\left(\mathrm{km}^{3} /\right.$ year $)$ & 14107.86 & 14143.04 & 14143.04 & 14154.36 & 14154.36 \\
\hline Withdrawal $\left(\mathrm{km}^{3} /\right.$ year$)$ & 61351.69 & 62191.48 & 62191.48 & 62228.12 & 62228.12 \\
\hline $\mathrm{CO}_{2}$ emissions $\left(\mathrm{MtCO}_{2} /\right.$ year) & 38.20 & 34.43 & 34.38 & 28.18 & 27.46 \\
\hline
\end{tabular}

\footnotetext{
${ }^{7}$ This is expressed in $\mathrm{m}^{3}$ of fresh feed per $\mathrm{m}^{3}$ of catalyst per hour. The inverse of LHSV is generally called residence time (STANISLAU et al, 2010).
} 


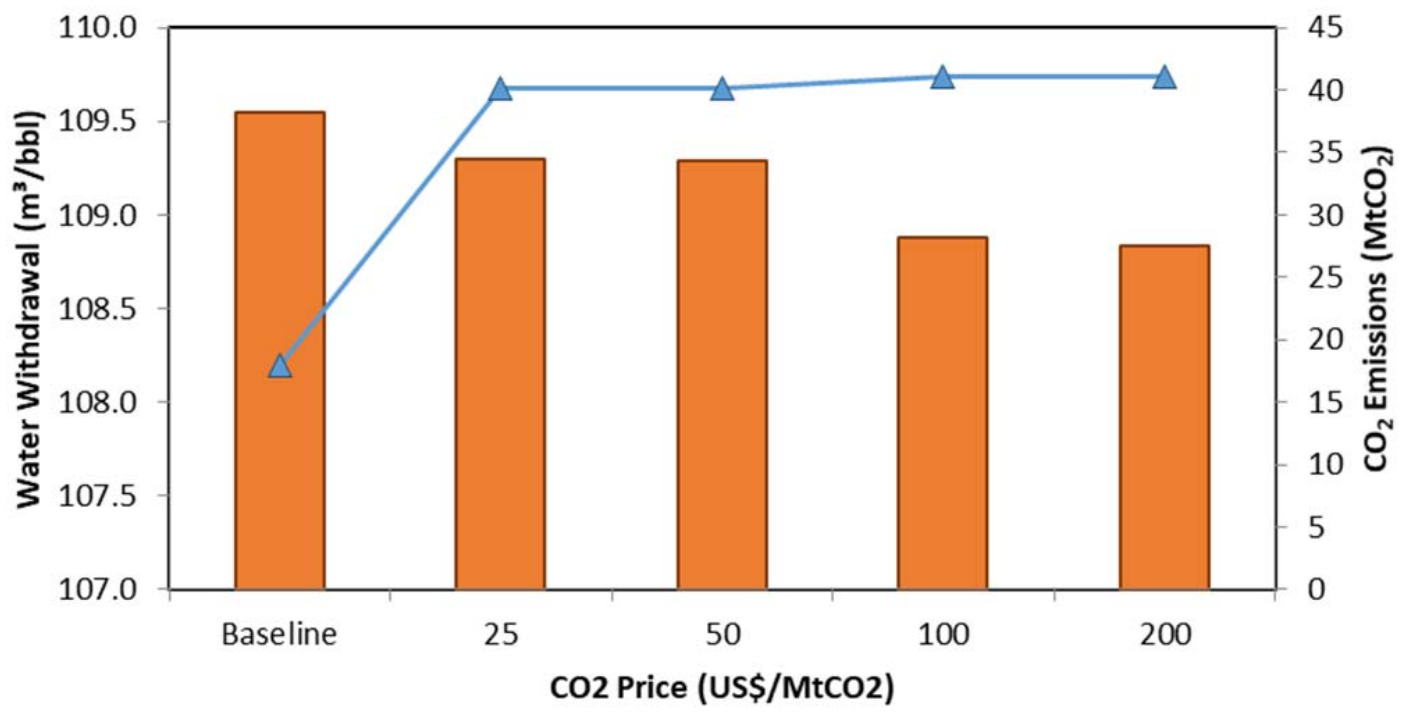

454 The most significant $\mathrm{CO}_{2}$ emission abatement occurs at 25 and $100 \mathrm{US} \$ / \mathrm{tCO}_{2}, 10 \%$ and $26 \%$, 455 respectively, compared to the baseline. This is explained by the total abatement potential of the 456 technologies found in the cost ranges 0-25 US\$/tCO $\mathrm{tCO}_{2}$ and 50-100 US\$/tCO $457205.7 \mathrm{MtCO}_{2}$ (see Supplementary Material). In respect to water requirements, a slight change of 458 less than $1 \%$ occurs between the baseline scenario and $25 \mathrm{US} \$ / \mathrm{tCO}_{2}$ scenario. In other 459 scenarios, the water withdrawals remain practically stable, with a small change, less than $0.5 \%$ 460 in the 100US $\$ / \mathrm{tCO}_{2}$ scenario. To better illustrate the relationship between the abatement costs 461 and the accumulated abatement potential, the abatement cost curve (Figure 6) was produced, 462 including the 204 technologies considered in the study. 


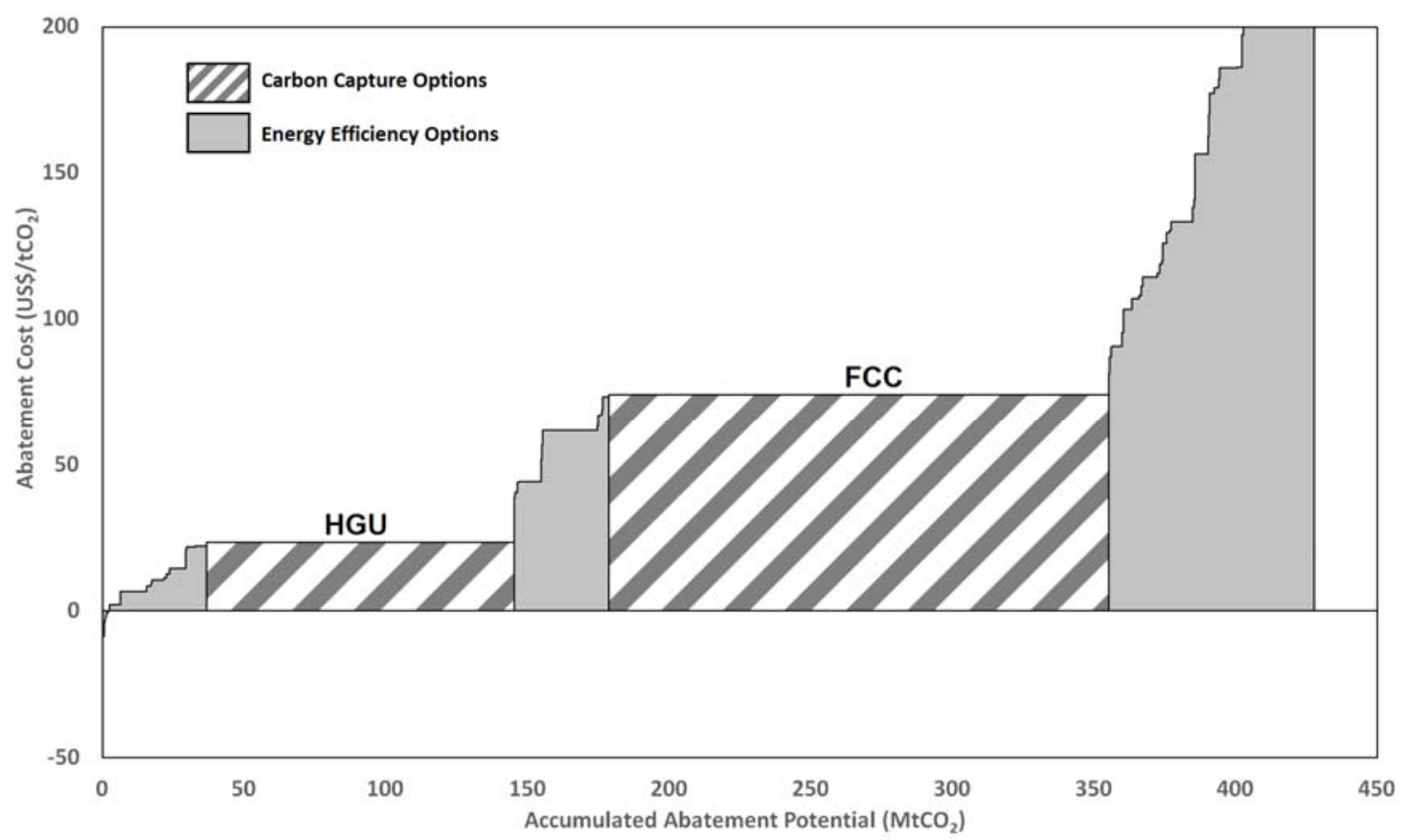

The graph performs a static analysis of the accumulated abatement potential of the mitigation options. For instance, it demonstrates that at a cost of $\$ 200 / \mathrm{tCO}_{2}$, it would be possible to implement a series of measures that have a cumulative abatement potential of $423.78 \mathrm{MtCO}_{2}$. The two striped areas marked on the graph represent the CC technologies, while the graycolored areas represent the other mitigation options. The first one, with an accumulated abatement potential of $145.5 \mathrm{MtCO}_{2}$, refers to the $\mathrm{HGU}$ capture with SMR/MDEA, while the second one, with $355.3 \mathrm{MtCO}_{2}$ of accumulated abatement potential, represents the $\mathrm{FCC}$ capture with Oxyfiring. These carbon capture technologies represent $65.7 \%$ of the total accumulated abatement cost, given the cracking pattern of Brazilian refineries and the recent regulations that tightened diesel and gasoline specifications in the country.

477 In the end, the findings of this study show that the co-benefits of GHG abatement measures that 478 also reduce steam consumption (e.g., reduction of heat storage between ADU and VDU, steam fouling reduction in $\mathrm{ADU}$, installation of vacuum pumps to replace steam injectors in ADU, increase AGR solvent concentration in HDS G, replace steam drive for electric in HDT N, and installation of CO-kiln in regenerative tower HRSG in FCC), which were $\operatorname{chosen}^{8}$ by our

\footnotetext{
${ }^{8}$ Steam fouling reduction in ADU and vacuum pumps to replace steam injectors in ADU are installed at $25 \mathrm{US} \$ / \mathrm{tCO}_{2}$. Increase AGR solvent concentration in $\mathrm{HDS} \mathrm{G}$ is chosen at $50 \mathrm{US} \$ / \mathrm{tCO}_{2}$. Replace steam drive for electric in HDT N is chosen at $100 \mathrm{US} \$ / \mathrm{tCO}_{2}$. CO-kiln in regenerative tower $\mathrm{HRSG}$ in FCC is installed at $200 \mathrm{US} \$ / \mathrm{tCO}_{2}$ tax.
} 
482 simulations, were offset by the water consumption increase related to CC options, especially in 483 HGU. In summary, at a national level and on average, $\mathrm{CO}_{2}$ mitigation impacts on water use by 484 oil refineries in Brazil are neutral. Figure 7 illustrates how steam consumption reduction from 485 some mitigation measures is overcome by the increase required with $\mathrm{CC}$ implementation.

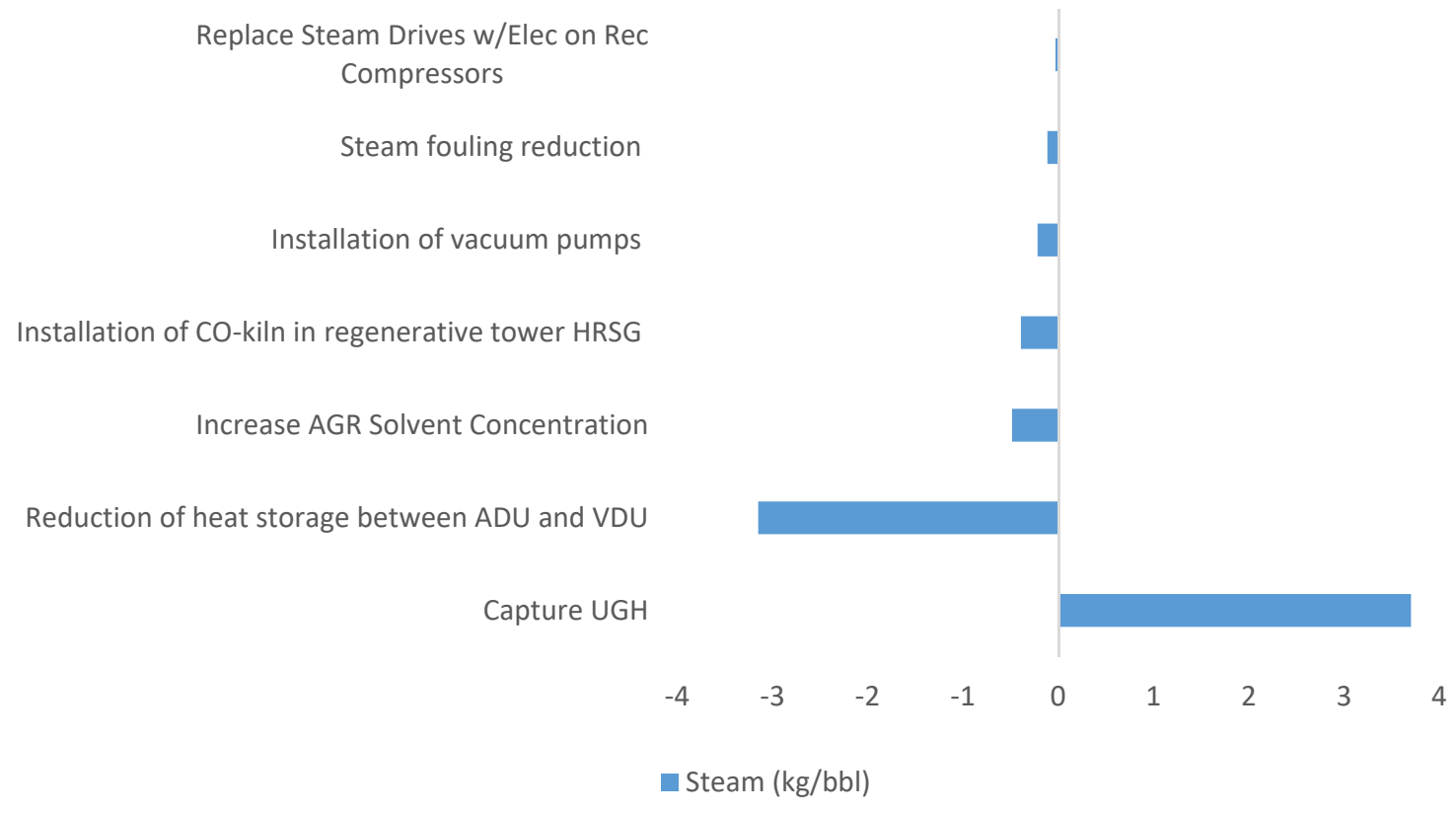

Figure 7 - Steam requirements impacts of $\mathrm{CO}_{2}$ mitigation options

\subsection{Case Study: REPLAN}

491 At a local level, for the largest Brazilian oil refinery, the water balance undertaken showed that, 492 although there was no unmet water demand at the REPLAN's catchment point, the conflict 493 between the multiple water users in the basin should intensify. This is due to the trend in the 494 river flow being progressively closer to the critical threshold of $50 \%$ of the minimum 495 availability $\left(\mathrm{Q}_{7,10}\right)$. In addition, it was observed that the point of flow observation at Jaguari 496 River faces instants when the flow must be restricted. This means that REPLAN may sometimes 497 suffer impacts on its operation due to a $30 \%$ reduction in the volume of water it receives from 498 the Jaguari River. 


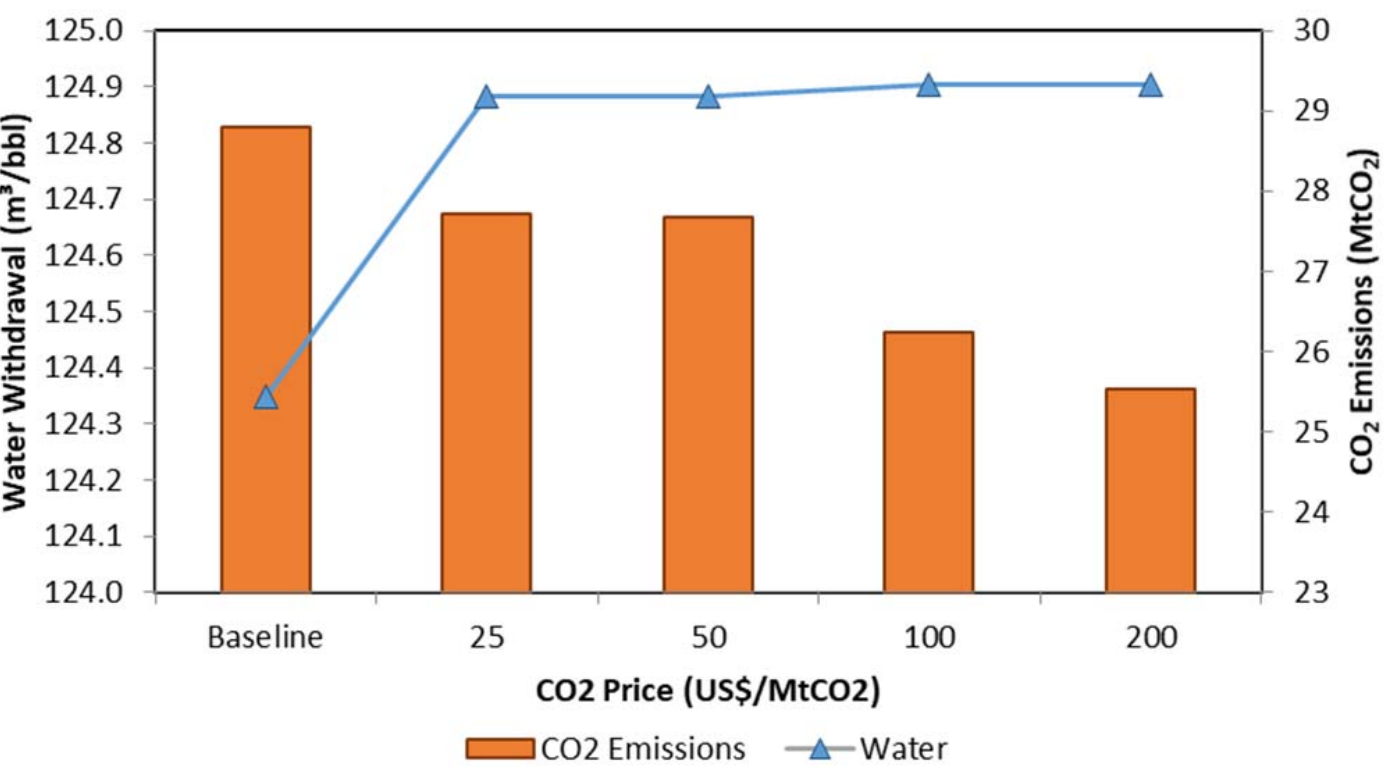

499

Figure 8 - Water withdrawal versus $\mathrm{CO}_{2}$ abatement in REPLAN

501

502

Figure 8 shows an increase in water withdrawal in all scenarios. Although some mitigation measures reduce steam consumption, in the refinery's overall water balance, this reduction is offset by the increase in the demand for boiler feed water and for cooling. Mitigation measures costing up to US\$ $25 / \mathrm{MtCO}_{2}$ were the ones that most demanded water due to the increase in boiler feed water need, which was $1.4 \%$ more than in the baseline scenario. In addition, the slight increase that occurred between scenarios US\$ $50 / \mathrm{MtCO}_{2}$ and 100 was due to the implementation of $\mathrm{CC}$, which increased the demand for cooling water.

Nevertheless, as a final balance, a reduction of less than $1 \%$ was obtained when implementing all $\mathrm{CO}_{2}$ mitigation measures in REPLAN. This means that, contrary to what happens in other energy sectors (ZHAI and RUBIN, 2011; MERSCHMANN et al., 2012), the implementation of $\mathrm{CO}_{2}$ abatement in oil refineries has no significant impact on water consumption (no negative trade-off). However, this also means that the water stress in oil refineries should be dealt with measures not directly linked to $\mathrm{CO}_{2}$ abatement (no significant co-benefits). This is valid both at

515 local and country levels.

519 This study developed an energy, $\mathrm{CO}_{2}, \mathrm{H}_{2}$, water balance simulator for Brazilian oil refineries, 520 and applied it to different scenarios of $\mathrm{CO}_{2}$ mitigation (at 25, 50, 100 and $200 \mathrm{US} \$ / \mathrm{tCO}_{2}$ ) 521 aiming at investigating the climate-energy-water nexus. A Baseline scenario, i.e., a scenario 
522 without $\mathrm{CO}_{2}$ prices was also elaborated. Results for both scenarios included final energy 523 consumption, $\mathrm{CO}_{2}$ emissions and water requirements. The most significant reductions in $\mathrm{CO}_{2}$

524 emissions were due to the implementation of the carbon capture. However, this option offsets

525 the co-benefits of $\mathrm{CO}_{2}$ abatement measures that reduced the water requirements of Brazilian oil

526 refineries, especially those already located in areas under water supply stress, such as the largest

527 refinery in Brazil (REPLAN), whose water balance with carbon mitigation options was detailed

528 in this study.

529 Nevertheless, as this study focused on the impacts of $\mathrm{CO}_{2}$ mitigation options on water 530 requirements, it was not able to follow the reverse path of the nexus: from climate to water 531 availability. This means that climate change can affect the water availability to oil refineries 532 (water supply, instead of water demand side). Hence, future studies could focus on this issue, 533 also including the analysis of alternatives to regularize river flows to deal with climate impacts 534 on water supply. Another idea could be optimizing refineries for minimizing water consumption 535 (or withdrawals).

536 It is also worth noting that this study tried to validate the findings of the tools used by 537 comparing them to real data from Brazil. However, an important issue for the simulation tool is 538 to calibrate the feedstock blend to be run, and the focus of the refinery operation. As of today, 539 although the Brazilian refinery system, on average, focuses on diesel optimization (e.g. when 540 establishing the distillation cuts), single refineries can present a different feature (e.g. focusing 541 on lube oils or petrochemicals). Similarly, the yearly focus of the average refinery operation on 542 diesel does not mean that this is valid for all days of the year.

543 Finally, although the $204 \mathrm{CO}_{2}$ mitigation options considered by this study represent an extensive 544 list of measures, there are always new possibilities to be assessed. For example, some studies 545 have evaluated the use of renewable energy sources to supply the energy demand (PINSKE et 546 al., 2012) and the hydrogen consumption (SILVA, 2017) of oil refineries.

\section{Acknowledgements}

550 We would like to acknowledge CAPES (Coordenação de Aperfeiçoamento de Pessoal de Nível 551 Superior) and $\mathrm{CNPq}$ (National Council for Scientific and Technological Development) for 552 financial support in the form of scholarships. We also thank IFP Energies nouvelles. 
ANA, 2017. Conjuntura dos Recursos Hídricos no Brasil. Regiões Hidrográficas. Brasília: Agência

557 Nacional de Águas. Available at: http://www.snirh.gov.br/portal/snirh/centrais-de-conteudos/conjuntura558 dos-recursos-hidricos/conj2017_rel_ingles-1.pdf (accessed 05.08.18).

ANP, 2018. Anuário Estatístico Brasileiro do Petróleo, Gás Natural e Biocombustíveis 2018. Agência

560 Nacional do Petróleo, Gás Natural e Biocombustíveis. Available at:

561 http://www.anp.gov.br/publicacoes/anuario-estatistico/anuario-estatistico-

562 2018\#Se\%C3\%A7\%C3\%A30\%202 (accessed 10.07.18).

563 ANZE, M., 2013. Otimização Do Uso De Água Em Refinarias De Petróleo. 160 p. - Universidade de São 564 Paulo, Brazil.

565 API - American Petroleum Institute, 2000. Technological Roadmap. Houston: API, 2000

566 BARAJAS, J., ROMAN, R., SOTELO, D., 2006. Multiplicity of steady states in FCC units: effect of 567 operating conditions. Fuel (85), 849-859.

568 BARROS, M.M., SZKLO, A., 2015. Petroleum refining flexibility and cost to address the risk of ethanol 569 supply disruptions: The case of Brazil. Renewable Energy (77), 20-31.

570 BERGH, C., 2012. Energy Efficiency in the South African Crude Oil Refining Industry: Drivers, Barriers 571 and Opportunities. Dissertação de Mestrado, Programa de Engenharia de Energia Sustentável, 572 Universidade de Cape Town, África do Sul.

573 CASTELO BRANCO, D., SZKLO, A., SCHAEFFER, R., 2010. CO2 emissions abatement costs of 574 reducing natural gas flaring in Brazil by investing in offshore GTL plants producing premium diesel. 575 Energy (35), 158-167.

576 CASTELO BRANCO, D.A., SZKLO, A., GOMES, G., BORBA, B.S.M.C., SCHAEFFER, R., 2011. 577 Abatement costs of $\mathrm{CO} 2$ emissions in the Brazilian oil refining sector. Applied Energy (11), 3782-3790.

578 CETESB, 2011. Licenciamento Ambiental Prévio de ampliação da Refinaria RPBC do empreendimento 579 Carteira de Diesel, São Paulo. Available at: 580 http://arquivos.ambiente.sp.gov.br/consema/2011/11/oficio_consema_2011_017/Parecer_Tecnico_CETE 581 SB_4055_11_TA_sobre_o_EIA-RIMA_da_Carteira_de_Diesel_da_RPBC.pdff (accessed 20.08.2018).

582 CHAN, W. N., 2006. Quantificação e redução de emissões de gases de efeito estufa em uma refinaria de 583 petróleo. Master Thesis, Universidade Estadual de Campinas.

584 COELHO, J. M. F., SZKLO, A., 2015. Dealing with petroleum surpluses in Brazil through optimization 585 refining model. Energy Strategy Reviews (6), 80-91.

586 CONCAWE, 2000. Carbon, Sulphur and hydrogen in oil refineries. Review, Volume 9, Number 1.

587 CONCAWE, 2008. Impact of product quality and demand evolution on EU refineries at the 2020 horizon $588 \mathrm{CO} 2$ emissions trend and mitigation options. Report 8/08, Belgium.

589 CONCAWE, 2012. Refinery energy systems and efficiency. Review, Volume 21, Number 1.

590 SILVA, G. N., 2017. Produção de hidrogênio renovável via Power to gas para mitigação de emissões de 591 CO2 do refino do petróleo e maior aproveitamento da energia eólica. Dissertação de Mestrado. Rio de 592 Janeiro: UFRJ/ COPPE/ Programa de Planejamento Energético.

593 DNV, 2010. Global Technology Roadmap for CCS in Industry - Sectoral Assessment: Refineries. Det 594 Norske Veritas, Research Report for UNIDO, London, United Kingdom.

595 EPA, 2010. Available and Emerging Technologies for Reducing Greenhouse Gas Emissions from the 596 Petroleum Refining Industry. United Stated Environmental Protection Agency. 
EPE, 2007. Plano Nacional de Energia 2030 / Ministério de Minas e Energia, colaboração Empresa de Pesquisa Energética. Brasília, Brazil. Available at: http://www.epe.gov.br/sites-pt/publicacoes-dadosabertos/publicacoes/PublicacoesArquivos/publicacao-165/topico-173/PNE\%202030\%20\%20Proje\%C3\%A7\%C3\%B5es.pdf (accessed 30.08.18).

GARCÍA, A. A. C, 2015. Challenge of the integration of $\mathrm{CO} 2$ capture in the refining sector. Club Español 604 de La Energía/ World Petroleum Council - Comitê Español.

605 GARY, J., H., HANDWERK, G. E., 2001. Petroleum Refining: Technology and Economics. 4th edition. 606 New York, United States.

607 Gary, J.H., Handwerk, G.E. and Kaiser, M.J., 2007. Petroleum Refining: Technology and Economics. 5th 608 edition, CRC Press, Boca Raton.

609 GOMES, G. L., SZKLO, A., SCHAEFFER, R., 2009. The impact of CO2 taxation on the configuration 610 of new refineries: An application to Brazil. Energy Policy (37), 5519-5529.

611 GUEDES, F. P. D. C., 2015. Avaliação de alternativas para redução do uso final de energia no setor de 612 refino de petróleo brasileiro e estimativa de custos de abatimento de emissões de gases de efeito estufa. 613 Dissertação de Mestrado. Rio de Janeiro: UFRJ/COPPE/ Programa de Planejamento Energético.

614 HALlACK, L. N., SZKLO, A. S, PEREIRA JÚNIOR, A. O., SCHMIDT, J., 2017. Curve-fitting 615 variants to model Brazil's crude oil offshore post-salt production. Journal of Petroleum Science and 616 Engineering (159), 230-243.

HIGHTOWER, M., PIERCE, S. A., 2008. The energy challenge. Nature (452), 285-286.

HWANG, S., MOORE, I., 2011. Water network synthesis in refinery. Korean Journal of Chemical 619 Engineering 28:1975.

HYDROCARBON PROCESSING, 2008. Refining Processes Handbook. CD-ROM, Gulf Publishing 621 Company, EUA.

622 IEA, 2016. World Energy Outlook 2016. International Energy Agency, Paris, France.

IEA GHG, 2008. Carbon Dioxide Capture and Storage in the Clean Development Mechanism: Assessing market effects of inclusion. IEA Greenhouse Gas R\&D Programme, Cheltenham.

IPCC, 2006. Guidelines for National Greenhouse Gas Inventories. National Greenhouse Gas Inventories Programme, Hayama, Japão. Available at: http://www.perf.org/images/Archive_Refining_Water.pdf (accessed 02.08.18).

JOHANSSON, D., ROOTZÉN, J., BERNTSSON, T., JOHNSOON, F., 2012. Assessment of strategies for $\mathrm{CO} 2$ abatement in the European petroleum refining industry. Energy (42), 375-386.

MAGALAR, L., 2018. Análise da disponibilidade hídrica como um fator de restrição à produção de derivados em refinarias. Rio de Janeiro: UFRJ/COPPE/ Programa de Planejamento Energético.

MAGNESCHI, G., ZHANG, T., MUNSON, R., 2017. The impact of CO2 capture on water requirements of power plants. Energy Procedia (114), $6337-6347$.

MCTI, 2013. Annual Estimates of Greenhouse Gas Emissions in Brazil (Estimativas anuais de emissões de gases de efeito estufa no Brasil). Brasília, Brasil.

MCTIC, 2018. Método da análise de despacho - Fatores de Emissão de CO2 pela geração de energia elétrica no Sistema Interligado Nacional do Brasil - Ano Base 2017. Ministério da Ciência, Tecnologia, Inovações 
642 MERSCHMANN, P. R. C., VASQUEZ, E., SZKLO, A. S., SCHAEFFER, R., 2012. Modeling water use 643 demands for thermoelectric power plants with CCS in selected Brazilian water basins. International 644 Journal of Greenhouse Gas Control (13), 87-101.

645 MEYERS, R. A., 2004. Handbook of Petroleum Refining Processes. 3rd edition. McGraw-Hill 646 Handbooks.

647 MME, 2018. Relatório do Mercado de Derivados de Petróleo. Número 148. Ministério de Minas e 648 Energia/ Secretaria de Petróleo, Gás Natural e Biocombustíveis/ Departamento de Combustíveis 649 Derivados de Petróleo.

650 MORROW III, W., MARANO, J., SATHAVE, J., HASANBEIGI, A., Xu, T., 2013. Efficiency 651 Improvement in the United States Petroleum Refining Industry. Environmental Energy Technologies 652 Division, California.

653 MUGHEES, W., AL-AHMAD, M., 2014. Application of Water Pinch Technology in Minimization of 654 Water Consumption at a Refinery. Computers \& Chemical Engineering (73), 34-42.

655 NOGUEIRA, D.M., 2007. Balanço Hídrico na Refinaria de Paulínia e Alternativas para Reuso de Água: 656 Construção de uma Ferramenta Auxiliar para o Gerenciamento dos Recursos Hídricos. Universidade 657 Estadual de Campinas.

658 OIL and GAS JOURNAL, 2018. 2018 World Wide Refining Survey.

659 PAN, L., LIU, P., MA, L., LI, Z., 2012. A supply chain based assessment of water issues in the coal 660 industry in China. Energy Policy (48), 93-102.

661 PETROBRAS, 2005. Estudo de Impacto Ambiental da Refinaria De Paulínia.

662 PETROBRAS, 2013. Relatório de Sustentabilidade 2013. Disponível em: 663 http://www.investidorpetrobras.com.br/pt/governanca/relatorio-de-sustentabilidade/relatorio-de664 sustentabilidade-2013.htm (accessed 30.07.2018)

665

666

667

668

669

670

671

PETROBRAS, 2016. Relatório de Sustentabilidade 2015. Available at: www.investidorpetrobras.com.br/download/4512 (accessed 11.07.18).

PINKSE, J., VAN DEN BUUSE, D., 2012. The development and commercialization of solar PV technology in the oil industry. Energy Policy (40), 11-20.

ROCHEDO, P. R. R.; SZKLO, A. S., 2013. Economic analysis under uncertainty of coal fired captureready power plants. International Journal of Greenhouse Gas Control, v. 12, p. 44-55. https://doi.org/10.1016/j.ijggc.2012.10.005

ROCHEDO, P. R. R., COSTA, I. V. L., IMPÉRIO, M., HOFFMANN, B. S., MERSCHMANN, P. R. C., OLIVEIRA, C. C. N., SZKLO, A., SCHAEFFER, R., 2016. Carbon capture potential and costs in Brazil. Journal of Cleaner Production (131), 280-295.

SCHOR, A.R., 2006. Riscos e alternativas para o abastecimento de água em uma refinaria de petróleo estudo de caso: refinaria duque de caxias - reduc. Universidade Federal do Rio de Janeiro.

SIEBER, J.; PURKEY, D., 2015. Water Evaluation And Planning System User Guide. [s.1: s.n.]. Available at: http://www.weap21.org/downloads/WEAP_User_Guide.pdf (accessed 05.01.16).

STANISLAUS, A.; MARAFI, A.; RANA, M. S., 2010. Recent advances in the science and technology of ultra-low sulfur diesel (ULSD) production. Catalysis Today, [s.1.], v. 153, no 1-2, p. 1-68, 2010. ISBN: 09205861, ISSN: 09205861, DOI: 10.1016/j.cattod.2010.05.011.

STRAELEN, J.; GUEZEBROEK, F.; GOODCHILD, N.; PROTOPAPAS, G.; MAHONY, L., 2010. International Journal of Greenhouse Gas Control (4), 316-320. 
686 SZKLO, A. S.; ULLER, V. C.; BONFÁ, M. H. P., 2012. Fundamentos do Refino do Petróleo. Tecnologia 687 e Economia. 3a Edição ed. Rio de Janeiro: Editora Interciência, 2012. 344 p.

688 SZKLO, A., SCHAEFFER, R., 2007. Fuel specification, energy consumption and CO2 emission in oil 689 refineries. Energy 32 (7), 1075-1092.

690 TOLMASQUIM, M. T.; SZKLO, A. S., 2000. Matriz Brasileira na Virada do Milênio. Rio de Janeiro: 691 COPPE/ UFRJ.

692 UNITED NATIONS, 2010. Carbon Capture and Storage in Industrial Applications: Technology 693 Synthesis Report. Working Paper, Vienna.

694 UNITED NATIONS, 2015. Transforming Our World: The 2030 Agenda for Sustainable Development. 695 Available at: https://sustainabledevelopment.un.org/post2015/transformingourworld/publication 696 (accessed 15.08.2018)

697 UNITED NATIONS, 2016. Sustainable Development Goals. Available in :

698 http://www.undp.org/content/undp/en/home/sustainable-development-goals.html (accessed 15.08.2018)

699 VANELLI, C.A., 2004. Conservação De Água Em Refinaria De Petróleo: O Caso Da Revap. Dissertação 700 de Mestrado. Programa de Pós-Graduação da Universidade Federal de Itajubá.

701 VÁSQUEZ ARROYO, E. M., 2018. Incorporação do nexo energia-água em um modelo de otimização da 702 expansão do sistema energético brasileiro. Rio de Janeiro: UFRJ/COPPE/ Programa de Planejamento 703 Energético.

704 VÁSQUEZ ARROYO, E. M., et al., 2016. A DISPONIBILIDADE HÍDRICA COMO POSSÍVEL 705 RESTRIÇÃO AMBIENTAL PARA A PRODUÇÃO DE DERIVADOS DE PETRÓLEO NO BRASIL. 706 In: Rio Oil \& Gas. [s.l.]: [s.n.].

707 WU, M., CHIU, Y., 2011. Consumptive water use in the production of ethanol and petroleum gasoline. 708 ANL/ESD/09-1, Argonne National Laboratory.

709 WORRELL, E.; GALITSKY, C., 2005. Energy Efficiency Improvement and Cost Saving Opportunities 710 for Petroleum Refineries. Environmental Energy Technologies Division, Ernest Orlando Lawrence 711 Berkeley National Laboratory, Califórnia, EUA.

712 WORRELL, E; GALITSKY, C., 2003. Profile of the Petroleum Refining Industry in California Industries 713 of the Future Program. Environmental Energy Technologies Division, Ernest Orlando Lawrence Berkeley 714 National Laboratory, Califórnia, EUA.

715 ZHAI, H., RUBIN, E. S., 2011. Carbon capture effects on water use at pulverized coal power plants. 716 Energy Procedia (4), 2238-2244. 